\title{
PENGETAHUAN DAN SIKAP IBU DALAM MENJAGA KEBERSIHAN MULUT PADA BAYI
}

\author{
Koekoeh Hardjito, RE Wijanti, Siti Fatkhur Rahmah
}

\begin{abstract}
Oral thrush often found in babies and young children who drink milk with bottle/pacifiers and children taking fopspeen is not clean. The exixtences of residual milk can also be the cause of these sariawan. One effort to prevent sariawan is to maintain mouth hygiene of children. The purpose of this study was to identify the correlation between knowledge of mother about sariawan with attitude of mother to do oral hygiene for a baby. Method is used in this research is study analyze correlation with used approximaly cross sectional. Population of this research is all mother which is had baby Sample in this research is 33 person From statistic test with standart errors 5\% (0.05) was gotten $\mathrm{p}=0,020<0.05$, so otherwise there is the correlation between knowledge of mother about sariawan with attitude of mother to do oral hygiene for a baby. Suggested to health staff for care increase service quality about health baby, So the mother can guard or correct the attitudes and behaviors in the care of her baby.
\end{abstract}

\section{Keyword : Knowledge, Attitude, Oral thrush, Oral Hygiene}

\section{Latar Belakang}

Sariawan (Thrush) sering dijumpai pada bayi dan anak kecil yang minum susu dengan botol atau dot atau anak kecil yang menghisap dot kempong (fonspeen) yang tidak diperhatikan kebersihannya (Ngastiyah, 2005). Penyakit ini dapat menyerang bagian permukaan dalam rongga mulut, bagian lidah dan gusi (Susanto, 2007).

Sariawan sering terjadi akibat rendahnya pengetahuan orang tua mengenai perawatan mulut bayi yang benar dan akibat kurang terjaganya kebersihan mulut bayi. Anak dari orang tua dengan tingkat sosial ekonomi yang rendah maupun tinggi dapat mengalami sariawan, apabila orang tuanya tidak mengetahui cara merawat bayi secara benar (Nursalam, 2005).

Prevalensi sariawan (stomatitis) bervariasi tergantung pada daerah populasi yang diteliti. Angka prevalensi stomatitis berkisar $15-25 \%$ dari populasi penduduk di seluruh dunia. Penelitian telah menemukan terjadinya stomatitis sekitar 2\% di Swedia (1985) 1,9\% di Spanyol (2002) dan 0,5\% di Malaysia
(2000). Stomatitis tampaknya jarang terjadi di Bedouins Kuwaiti yaitu sekitar $5 \%$ dan ditemukan $0,1 \%$ pada masyarakat India di Malaysia. Di Indonesia belum diketahui berapa prevalensi stomatitis di masyarakat, tetapi dari data klinik penyakit mulut di rumah sakit Ciptomangun Kusumo, periode 20032004 didapatkan prevalensi stomatitis dari 101 pasien terdapat kasus stomatitis 17,3\%.

Penyebab sariawan (thrush) pada umumnya adalah candida albicans yang ditularkan melalui vagina ibu yang terinfeksi selama persalinan (saat bayi lahir) atau tranmisi melalui susu botol dan puting susu yang tidak bersih, atau cuci tangan yang tidak benar. Pada bayi baru lahir, biasanya timbul pada 7-10 hari setelah lahir (Sefrina, 2012). Dampak sariawan jika dibiarkan dan tidak segera ditangani maka asupan nutrisi yang masuk dalam tubuh bayi akan berkurang. Masalah tersebut juga dapat mengakibatkan diare karena jamur dapat tertelan dan menimbulkan infeksi usus yang bila dibiarkan dan tidak diobati maka bayi akan terserang diare seringkali 
kondisi ini dianggap sebagai hal yang wajar dan kurang diperhatikan oleh orang tua(Ngastiyah, 2005).

Data dari Dinkes Kabupaten Kediri Tahun 2013 jumlah Bayi di Puskesmas Papar sebanyak 723 Bayi, di Desa Minggiran Kecamatan Papar Kabupaten Kediri didapatkan 47 ibu yang mempunyai bayi, 4 ibu diantaranya pernah membawa anaknya ke Bidan Praktek dengan keluhan rewel, tidak mau minum dan terdapat bercak putih kekuningan pada lidah. Kondisi ini merupakan tanda adanya sariawan pada bayi. Penelitian ini bertujuan mengetahui hubungan antara pengetahuan ibu tentang sariawan dengan sikap ibu dalam menjaga kebersihan mulut pada bayi.

\section{Metode Penelitian}

Penelitian analitik ini menggunakan pendekatan cross-sectional dimana variabel bebas yaitu pengetahuan dan variabel terikat yaitu sikap diukur pada waktu yang bersamaan. Penelitian dilaksanakan di Desa Minggiran Kecamatan Papar pada bulan Juni 2014 dengan sampel sebesar 33 ibu dan teknik pengambilan sampel secara random. Instrumen yang digunakan dalam penelitian ini berupa kuesioner untuk pengetahuan dan sikap. Bila responden mampu menjawab dengan benar sebesar $75 \%$ atau lebih maka dikategorikan dalam pengetahuan baik, jika kurang dari $75 \%$ maka masuk dalam kategori pengetahuan kurang. Untuk sikap menggunakan patokan nilai rata-rata yang diperoleh responden. Jika responden mendapatkan skor $\geq$ nilai rata rata sikap dari seluruh responden maka masuk dalam kategori sikap positif, jika kurang dari rata-rata tergolong sikap negatif. Uji yang digunakan adalah fisher exact pada $\alpha 0.05$.

\section{Hasil Penelitian}

Hasil Penelitian ditunjukkan dalam diagram di bawah ini:

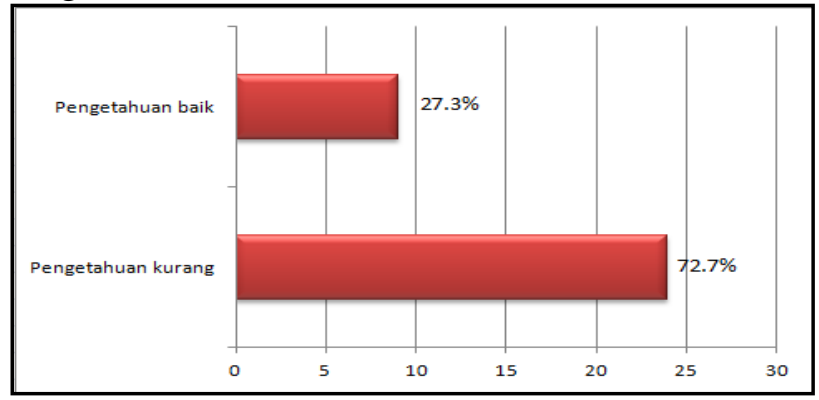

Gambar 1. Pengetahuan responden tentang sariawan

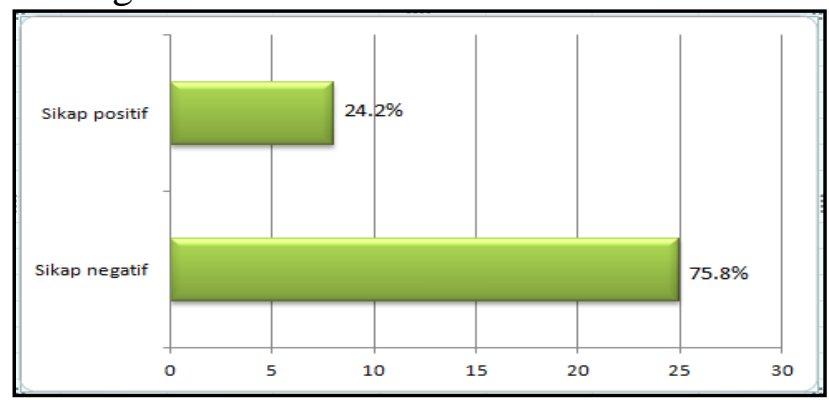

Gambar 2. Sikap responden dalam menjaga kebersihan mulut bayi

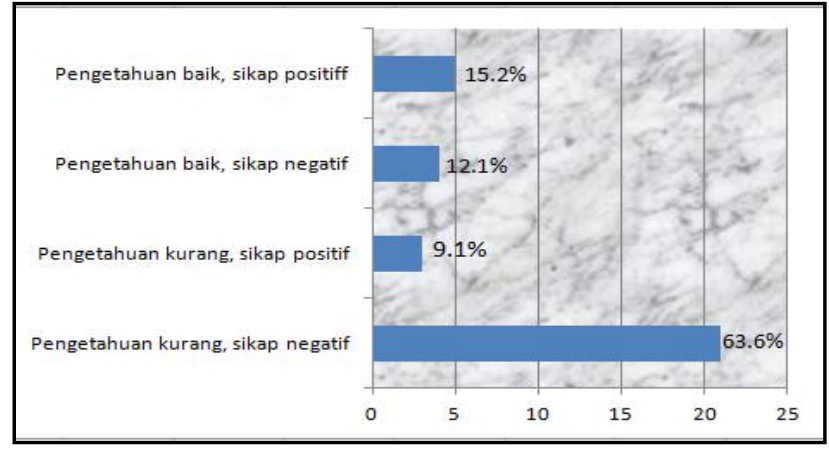

Gambar 3. Distribusi pengetahuan dan sikap responden

Sebagian besar responden memiliki pengetahuan yang kurang tentang sariawan dan memiliki sikap negatif dalam menjaga kebersihan mulut bayi. Hasil uji statistic dengan Fisher Exact menunjukkan P-value 0.02, lebih kecil dari $\alpha 0.05$, sehingga terdapat hubungan antara pengetahuan ibu tentang sariawan dengan sikap ibu dalam menjaga kebersihan mulut bayi.

\section{Pembahasan}

Responden yang mempunyai pengetahuan kurang mayoritas tidak mengerti tentang akibat yang ditimbulkan 
sariawan ini bila dibiarkan terlalu lama. Menurut Ngastiyah (2005) sariawan dapat mengakibatkan diare karena jamur dapat tertelan dan menimbulkan infeksi usus yang bila dibiarkan dan tidak diobati. Dengan keadaan ini ibu menjadi tidak antusias untuk mencari tahu pencegahan dari masalah sariawan ini. Seringkali sariawan dianggap sebagai suatu hal yang sepele.

Beberapa hal yang menjadikan pengetahuan yang kurang adalah subyek dari informasi yang dinilai kurang menarik ataupun kurang berarti bagi seseorang. Informasi inilah merupakan sumber pengetahuan yang dapat diperoleh dengan berbagai cara. Salah satu cara mendapatkan informasi adalah dengan membaca, sesuai dengan pendapat Ernia Karina, 2014 bahwa apapun yang kita baca akan menambah pengetahuan kita. Kesempatan membaca yang dimiliki oleh responden bisa menjadi alasan mengapa pengetahuan responden berada pada kategori kurang.

Penilaian sikap dalam penelitian ini menggunakan patokan nilai rata-rata dari keseluruhan responden, hasilnya menunjukkan bahwa terdapat responden yang sangat memperhatikan kebersihan mulut bayi namun juga terdapat responden yang kurang memperhatikan. Seringkali dijumpai di masyarakat bahwa kebersihan gigi bukanlah hal yang penting untuk diperhatikan terutama pada bayi yang belum memiliki gigi, masalah seringkali dihubungkan dengan kebersihan gigi. Hal inilah yang menjadikan rendahnya perhatian responden terhadap pentingnya menjaga kebersihan mulut bayi.

Menurut Wawan ddk, 2011 sikap dapat berubah pada seseorang bila terdapat keadaan tertentu yang mempermudah sikap pada orang tersebut, juga disebutkan bahwa sikap seseorang dipengaruhi oleh kebudayaan, tanpa disadari kebudayaan telah menanamkan garis pengarah sikap terhadap berbagai masalah. Dalam masyarakat, pencegahan terhadap sariawan ini dipandang sebagai tindakan yang tidak penting, tidak perlu dilakukan. Mereka masih awam dengan tindakan ini. Keyakinan seperti itu terbentuk dari orangtua atau mertua yang memberikan pengaruh yang besar terhadap sikap ibu dalam melaksanakan kebersihan mulut.

Faktor lingkungan juga sangat mempengaruhi sikap ibu dalam melaksanakan kebersihan mulut. Walaupun ibu mengetahui tentang sariawan tetapi lingkungan tidak memberikan dukungan positif untuk melaksanakan kebersihan mulut, maka sikap ini juga tidak akan terbentuk, ini diperkuat dengan teori dari Nursalam (2005) Lingkungan merupakan seluruh kondisi yang ada disekitar manusia dan pengaruhnya dapat mempengaruhi perkembangan dan perilaku.

Untuk dapat menjadi dasar pembentukan sikap, pengalaman pribadi haruslah meninggalkan kesan yang kuat. Karena itu, sikap akan lebih mudah terbentuk apabila pengalaman pribadi tersebut terjadi dalam situasi yang melibatkan faktor emosional. Ibu yang sudah mempunyai banyak pengalaman bagaimana pentingnya melakukan kebersihan mulut akan semakin baik pula sikap yang terbentuk. Sikap diperoleh dari diri sendiri atau orang lain yang paling dekat. Sikap membuat seseorang mendekati atau menjauhi orang lain. Sikap positif terhadap nilai-nilai kesehatan tidak selalu terwujud dalam suatu tindakan yang nyata.

Berdasar teori health believe model bahwa Kesiapan Individu untuk merubah perilaku dalam rangka menghindari suatu penyakit atau memperkecil resiko kesehatan adalah adanya dorongan dalam lingkungan individu yang membuatnya merubah perilaku dan perilaku itu sendiri. Kesiapan individu dipengaruhi oleh faktor seperti persepsi tentang kerentanan terhadap penyakit, potensi ancaman, dan adanya kepercayaan bahwa perubahan perilaku akan memberikan keuntungan. Konsep ini berkaitan erat dengan hasil 
penelitian yang menunjukkan

pengetahuan yang kurang akan menjadikan sikap yang kurang juga dalam menjaga kebersihan mulut bayi.

\section{Simpulan Dan Saran}

Sebagian besar responden memiliki pengetahuan yang kurang tentang sariawan. Sebagian besar besar responden memiliki sikap negatif dalam menjaga kebersihan mulut bayi. Terdapat hubungan antara pengetahuan ibu tentang sariawan dengan sikap ibu dalam menjaga kebersihan mulut bayi.

Saran kepada tenaga kesehatan untuk meningkatkan kualitas layanan kesehatan yang diberikan pada ibu yang mempunyai bayi dengan memberikan sehingga ibu lebih memahami tentang gangguan pada mulut bayi ini. Perubahan pemahaman tentang dampak yang dapat ditimbulkan oleh adanya sariawan perlu lebih ditingkatkan pada masyarakat.

DAFTAR PUSTAKA

Ernia Karina, 2014. Alasan mengapa harus rajin membaca. http://www.hipwee.com/motivasi/in i-loh-alasan-kenapa-kamu-harusrajin-membaca/

Ngastiyah.2005. Perawatan Anak Sakit. Jakarta: EGC

Nursalam dkk. 2005. Asuhan Keperawatan Bayi\&Anak (Untuk Perawat \& Bidan). Jakarta: Salemba Medika

Sefrina, A. 2012. Mengenal, Mencegah, Menangani Berbagai Penyakit Berbahaya Bayi dan Balita. Jakarta Timur: Dunia Sehat

Susanto, A. 2007. Kesehatan Gigi dan Mulut. Jakarta: PT Sunda Kelapa Pustaka

Wawan A dan M. Dewi.2011. Pengetahuan, Sikap, dan Perilaku Manusia.Yogyakarta: Nuha Medika 